Article

\title{
Antifungal Activity of the Extract of a Macroalgae, Gracilariopsis persica, against Four Plant Pathogenic Fungi
}

\author{
Latifeh Pourakbar $^{1, *}$, Sina Siavash Moghaddam ${ }^{2}$, Hesham Ali El Enshasy ${ }^{3,4,5}(\mathbb{D})$ and R. Z. Sayyed ${ }^{6}(\mathbb{D}$ \\ 1 Department of Biology, Faculty of Science, Urmia University, Urmia 5756151818, Iran \\ 2 Department of Plant Production and Genetics, Faculty of Agriculture, Urmia University, \\ Urmia 5756151818, Iran; sinamoghaddam2003@gmail.com \\ 3 Institute of Bioproduct Development (IBD), Universiti Teknologi Malaysia (UTM), Skudai, \\ Johor Bahru 81310, Johor, Malaysia; henshasy@ibd.utm.my \\ 4 School of Chemical and Energy Engineering, Faculty of Engineering, Universiti Teknologi Malaysia (UTM), \\ Skudai, Johor Bahru 81310, Johor, Malaysia \\ 5 City of Scientific Research and Technology Applications (SRTA), New Burg Al Arab, Alexandria 21934, Egypt \\ 6 Department of Microbiology, PSGVP Mandal's, Arts, Science \& Commerce College, Shahada 425409, India; \\ sayyedrz@gmail.com \\ * Correspondence: 1.pourakbar@urmia.ac.ir
}

check for updates

Citation: Pourakbar, L.;

Moghaddam, S.S.; Enshasy, H.A.E.; Sayyed, R.Z. Antifungal Activity of the Extract of a Macroalgae, Gracilariopsis persica, against Four Plant Pathogenic Fungi. Plants 2021, 10, 1781. https://doi.org/10.3390/ plants10091781

Academic Editors: Špela Mechora and Dragana Šunjka

Received: 27 July 2021

Accepted: 24 August 2021

Published: 26 August 2021

Publisher's Note: MDPI stays neutral with regard to jurisdictional claims in published maps and institutional affiliations.

Copyright: (c) 2021 by the authors. Licensee MDPI, Basel, Switzerland. This article is an open access article distributed under the terms and conditions of the Creative Commons Attribution (CC BY) license (https:/ / creativecommons.org/licenses/by/ $4.0 /)$.

\begin{abstract}
Nowadays, the extract of seaweeds has drawn attention as a rich source of bioactive metabolites. Seaweeds are known for their biologically active compounds whose antibacterial and antifungal activities have been documented. This research aimed to study the profile of phenolic compounds using the HPLC method and determine biologically active compounds using the GC-MS method and the antifungal activity of Gracilariopsis persica against plant pathogenic fungi. G. persica was collected from its natural habitat in Suru of Bandar Abbas, Iran, dried, and extracted by methanol. The quantitative results on phenolic compounds using the HPLC method showed that the most abundant compounds in G. persica were rosmarinic acid $(20.9 \pm 0.41 \mathrm{mg} / \mathrm{kg} \mathrm{DW})$ and quercetin $(11.21 \pm 0.20 \mathrm{mg} / \mathrm{kg} \mathrm{DW})$, and the least abundant was cinnamic acid $(1.4 \pm 0.10 \mathrm{mg} / \mathrm{kg} \mathrm{DW})$. The GCMS chromatography revealed 50 peaks in the methanolic extract of G. persica, implying 50 compounds. The most abundant components included cholest-5-en-3-ol (3 beta) $(27.64 \%)$, palmitic acid (17.11\%), heptadecane $(7.71 \%)$, and palmitic acid methyl ester $(6.66 \%)$. The antifungal activity of different concentrations of the extract was determined in vitro. The results as to the effect of the alga extract at the rates of $200,400,600,800$, and $1000 \mu \mathrm{L}$ on the mycelial growth of four important plant pathogenic fungi, including Botrytis cinerea, Aspergillus niger, Penicillium expansum, and Pyricularia oryzae, revealed that the mycelial growth of all four fungi was lower at higher concentrations of the alga extract. However, the extract concentration of $1000 \mu \mathrm{L}$ completely inhibited their mycelial growth. The antifungal activity of this alga may be related to the phenolic compounds, e.g., rosmarinic acid and quercetin, as well as compounds such as palmitic acid, oleic acid, and other components identified using the GC-MS method whose antifungal effects have already been confirmed.
\end{abstract}

Keywords: biologically active compounds; fungistatic effects; quercetin; red alga; rosmarinic acid

\section{Introduction}

Algae are autotrophic organisms that contain chlorophyll but lack flowering organs or real roots, stems, and leaves and can convert solar energy into chemical energy by photosynthesis [1]. Macroalgae, or seaweeds, have long been used as a source of food, forage, fertilizer, and medication. Seaweeds provide many raw materials, including agar, algin, and carrageenan used in many industrial sectors. Moreover, they are consumed as food in many Asian countries [2] because they contain carotenoids, diet fibers, proteins, necessary fatty acids, vitamins, and minerals required for human nutrition [3]. Depending on their phylum, growth stage, and environmental conditions, algae can contain different 
amounts of bioactive compounds, including secondary metabolites, that could exhibit antiviral, antibacterial, and antifungal activities [4-7].

Plant diseases, especially those caused by plant pathogenic fungi, are key factors in the production and quality of crops [8-10] and in the postharvest life of fresh fruit and vegetables [11]. Among these pathogens, Pyricularia oryzae (P. oryzae) and Botrytis cinerea (B. cinerea) are two globally distributed fungi with a wide range of hosts, ranked as the first and second most important plant pathogens in the world based on their economic and scientific importance [12]. Known as the cause of rice blast disease, P. oryzae is the most damaging rice disease in the world. It is reported that it annually destroys $10-30 \%$ of the rice crop, sometimes reaching $100 \%$ in the case of an epidemic $[12,13]$. B. cinerea is responsible for various diseases, e.g., blossom blight, leaf spot, and fruit and bulb rot, both on farms and post-harvest crops. Since the organs of the infectious agent grow on the surface of the infected tissues, the developed infection is called gray mold [14]. Aspergillus niger is one of the most dominant species from the genus Aspergillus, which is responsible for black mold disease in fruits and vegetables [15,16]. It is also known as the common contaminant of foods, especially in sun-dried foods, grains, and nuts, and is the primary agent of postharvest rot of fruits and vegetables. In addition, it is regarded as an opportunistic pathogen of humans [17]. Penicillium expansum is known as the cause of blue mold or soft rot in many vegetables and fruits in the world. Its name originated from the blue-color conidium masses that it produces in the infected parts $[18,19]$. This species is the most important postharvest pathogen of apples and pears as it not only damages them extensively during storage but is also vital, as it produces the carcinogen toxin patulin in the infected fruits used to make fruit juice [20].

There are different ways to control diseases, e.g., the use of resistant cultivars, agronomic practices such as the use of healthy seeds, the balanced use of fertilizers, and biological and chemical control methods [21]. As a result of the frequent use of fungicides, some fungal isolates have become resistant to different fungicide groups [22]; therefore, these fungicides can be used limitedly in disease control [23,24]. It is, therefore, necessary to find new chemicals or use effective natural substances to control the disease.

Moisture on plants is a major factor involved in the fungal infections of these four fungal diseases. The current strategies to control fungal diseases include preventing moisture on leaf area for a prolonged period, the development of resistance in the host plants, and the application of fungicides. Nowadays, various artificial fungicides are applied for the protection of plants from these diseases [21]. Interest is growing in research on the industrial application of medicinal plants due to increasing attention to the use of natural antioxidants and fungicides as an alternative to synthetic ones, which are unsafe and toxic. Recently, many studies have reported the antifungal and antimicrobial activities of algae extracts, essential oils, and other materials. The number of compounds derived from various families of macroalgae, including green algae, brown algae, and red algae, is estimated at 40,000 , which plays a key role in plant protection and improvement and is indeed a new approach for pest management $[25,26]$.

Gracilaria is a genus of red algae with a global spread found in polar, moderate, and hot regions, but most of its species have been reported in tropical waters [27]. Research on the coastal areas in Southern Iran has detected a species of these algae in the Persian Gulf called Gracilariopsis persica (Rhodophyta) [28].

Most synthetic fungicides can potentially be harmful to the environment and can leave toxic residues in soil and/or crops [29]. Therefore, it is of crucial significance to find new biodegradable natural and eco-friendly bioactive compounds that possess potential biorational activity [30]. Accordingly, a goal we pursued in this research was to assess and examine natural active ingredients in the extract of G. persica using HPLC and GC-MS methods with a focus on its biorational effect (relatively non-toxic with few environmental side effects) against four pathogenic fungi. 


\section{Materials and Methods}

\subsection{Sampling from G. persica}

Algae seedlings were collected from their natural habitat in Suru of Bandar Abbas, Iran at high water on November 16, 2018. In the habitat of G. persica on the transect, three transects were selected parallel to the coast. Samples were randomly taken by throwing $50 \times 50 \mathrm{~cm}$ quadrats in five replications and cutting the seedlings in each quadrat with a spatula from their joining to the sand bed. The samples were placed within moist Kenaf fibers (damped by seawater) in multiple layers. They were then transferred to a laboratory with coolers [31]. The thalli collected from the natural habitat were placed in an aquarium for $24 \mathrm{~h}$. The aquarium for the seawater was filled with 40-ppt saline water and kept at $25-27^{\circ} \mathrm{C}$ with aeration. The thalli of the algae were rinsed with the water of the related aquarium to remove mud and unwanted epiphytes.

\subsection{Extraction to Assess Antifungal Activity}

The collected algae were dried for 1 week in the ambient shade drying conditions at an average temperature of $27^{\circ} \mathrm{C}$ and after grinding, their powder was used for extraction. Therefore, $50 \mathrm{~g}$ of the ground alga's dry matter was poured into a 500-milliliter Erlenmeyer flask where $200 \mathrm{~mL}$ of methanol was added. It was then shaken at $25^{\circ} \mathrm{C}$ for 10 days, and its extract was filtered through a grade 2 Whatman ${ }^{\circledR}$ filter paper. The extract was dried with an evaporator and kept in a sterilized sealed glass container in darkness at $4{ }^{\circ} \mathrm{C}$ [32]. Then, to check the antifungal effects, the dried extract was dissolved in water.

\subsection{Preparation of Methanolic Extract for HPLC and GC-MS Analysis}

Two $g$ of the powdered alga sample were added to $25 \mathrm{~mL}$ of methanol containing $1 \%$ acetic acid, placed in a magnetic shaker for $3 \mathrm{~h}$, and filtered by grade 1 Whatman ${ }^{\circledR}$ filter paper.

\subsection{Analysis of Methanol Extract by Gas Chromatograph-Mass Spectrometry (GC-MS)}

The methanolic extract of the alga was analyzed using Agilent 7890A Gas Chromatography/Mass Spectrometry (GC/MS) (Agilent 7890A, Agilent Technologies Inc., Santa Clara, CA, USA) and 5975 A mass spectrophotometer using an HP-5 MS capillary column (polydimethylsiloxane with a length of $30 \mathrm{~m}$, an internal diameter of $0.25 \mathrm{~mm}$, and a thickness of $0.25 \mu \mathrm{m}$ ). The initial temperature of the oven was set to increase from 80 to $180^{\circ} \mathrm{C}$ at a rate of $8{ }^{\circ} \mathrm{C} / \mathrm{min}$. Helium was used as the carrier gas whose speed was $1 \mathrm{~mm} / \mathrm{min}$ along the column length. The injection valve was set in the split mode at a ratio of 1:500 and an injection temperature of $250^{\circ} \mathrm{C}$. The mass spectrum was $40-500$ mass/load and ionization energy of $70 \mathrm{eV}$. The whole run time was $55 \mathrm{~min}$. The mass libraries Wily 2007 and NIST were employed to identify the compounds. Data were processed in the Windows-based Chemstation software. The relative percentage of the extract constituents was expressed in percent based on the peak level.

\subsection{Measurement of Phenol Compounds by the HPLC Method}

The phenolic compounds were isolated, detected, and quantified using High-Performance Liquid Chromatography HPLC (Agilent 1100, Agilent Technologies Inc., Santa Clara, CA, USA) equipped with a 20-microliter injection loop, a four-solvent gradient pump, a degasser, a column oven (set at $25^{\circ} \mathrm{C}$ ), and a diode array detector set at 250, 272, and $310 \mathrm{~nm}$.

The isolation was carried out by an Octadecyl Saline Column (ODC) (with a length of $25 \mathrm{~cm}$, an internal diameter of $4.6 \mathrm{~mm}$, and a particle size of $5 \mu \mathrm{m}$, ZOR BAX Eclipse $\mathrm{XDB}$, Germany). Data were processed using the Chemstation software. The mobile phase consisted of acetic acid (1\%) (A) and acetonitrile (B) at a flow rate of $1 \mathrm{~mL} / \mathrm{min}$. The phenolic compounds were eluted under the following conditions: $1 \mathrm{~mL} / \mathrm{min}$ of flow rate, the temperature of $25{ }^{\circ} \mathrm{C}$, isocratic conditions from 0 to $10 \mathrm{~min}$ with $10 \% \mathrm{~B}$, gradient conditions from 10 to $25 \%$ B in $5 \mathrm{~min}$, from 25 to $65 \%$ B in $10 \mathrm{~min}$, from 65 to $100 \%$ B in $15 \mathrm{~min}$, followed by washing and reconditioning the column. The injection volume was 
$10 \mu \mathrm{L}$ and phenolic compounds were detected at wavelengths of 250,272 , and $310 \mathrm{~nm}$. The phenolic compounds were identified by comparing their relative retention times and compared with standards [33].

\subsection{Preparation of Potato Dextrose Agar (PDA)}

Fifty $g$ of peeled Irish potatoes were rinsed after slicing and boiled for $1 \mathrm{~h}$ with distilled water in a conical flask. A muslin cloth was applied to filter the boiled potatoes and the volume was increased to $250 \mathrm{~mL}$ with water along with dextrose $(5 \mathrm{~g})$ and agar $(3.5 \mathrm{~g})$. The suspension was dissolved with heat and shaking, then left to cool down at room temperature for two min, then sterilized in an autoclave at $121{ }^{\circ} \mathrm{C}$ for one $\mathrm{h}$.

\subsection{In Vitro Antifungal Activity of the Extract}

The antifungal effect of the extract of G. persica was checked using the following method. The fungi B. cinerea, P. oryzae, A. niger, and P. expansum were purchased from the Fungi and Bacteria Collection Center of Iran and cultured in a laboratory. To evaluate the antifungal activity of the alga extract, 200, 400, 600, 800, and $1000 \mu \mathrm{L}$ of the extract were poured on sterile PDA plates. Distilled water was chosen as the control. Then, a ring with a diameter of $5 \mathrm{~mm}$ was taken from the margin of the actively growing colonies of the fungi and transferred to the center of the culture medium. All inoculated plates were kept in an incubator at $25{ }^{\circ} \mathrm{C}$ and were checked daily until the surface of the culture medium was entirely covered with the fungi in the control treatments. Then, the radial growth of the fungi was measured. The extract inhibitory effect on the mycelial growth of the fungi was calculated for each concentration by using the following formula [34]:

$$
\operatorname{MGI}(\%)=\frac{d c-d t}{d c} \times 100
$$

where MGI is the mycelial growth inhibition, $d c$ is the mean diameter $(\mathrm{mm})$ of the fungal mycelial growth in the control treatment, and $d t$ is the mean diameter $(\mathrm{mm})$ of the fungal mycelial growth extract-containing treatment.

\subsection{Fungistatic or Fungicide Effect of the Extract}

At the end of the trials, another experiment was conducted on the treatments in which no growth was observed to determine whether the extracts had killed the fungi (fungicidal effect) or had inhibited their growth temporarily (fungistatic effect). For this experiment, a PDA culture medium that contained no additive was prepared and poured into Petri dishes. The fungi-containing rings from the treatments that had no growth were transferred to the new culture medium. The Petri dishes were placed in an incubator at $25{ }^{\circ} \mathrm{C}$ and were re-checked after 7 days. The treatments in which the mycelial growth was observed after 7 days showed the fungistatic activity of the extract, while the lack of mycelial growth in the fungi-containing ring in the culture medium exhibited its fungicide activity.

\subsection{Data Analysis}

The data were subjected to the analysis of variance (ANOVA) and the comparison of means in the SPSS (Ver. 16) software package. The mean values were compared with Duncan's multiple range test. In all graphs, the results were expressed in average values of three replications \pm standard deviation (SD). Additionally, the graphs were drawn in MS-Excel (2016) software package.

\section{Results}

\subsection{Results of GC-MS}

The biologically active components in the methanolic extract of G. persica were detected using GC-MS with a running time of $55 \mathrm{~min}$. The GC-MS chromatogram showed 50 peaks in methanolic extract, implying 50 compounds (Figure 1). The spectra of these compounds were compared with Wiley 7.0 and National Institute of Standards and Technology libraries. 
The detected compounds are listed in Table 1. The main fractions included cholest-5-en-3-ol (3. beta), palmitic acid, heptadecane, palmitic acid methyl ester, bicyclo [3.1.1] heptane, 2,6,6-trimethyl or pinane, isobutyl phthalate, $N$-cyano- $N^{\prime}, N^{\prime}, N^{\prime \prime}, N^{\prime \prime}$-tetramethyl-1,3,5triazinetriamine, 5-thiazoleethanol, 4-methyl, and phytol.

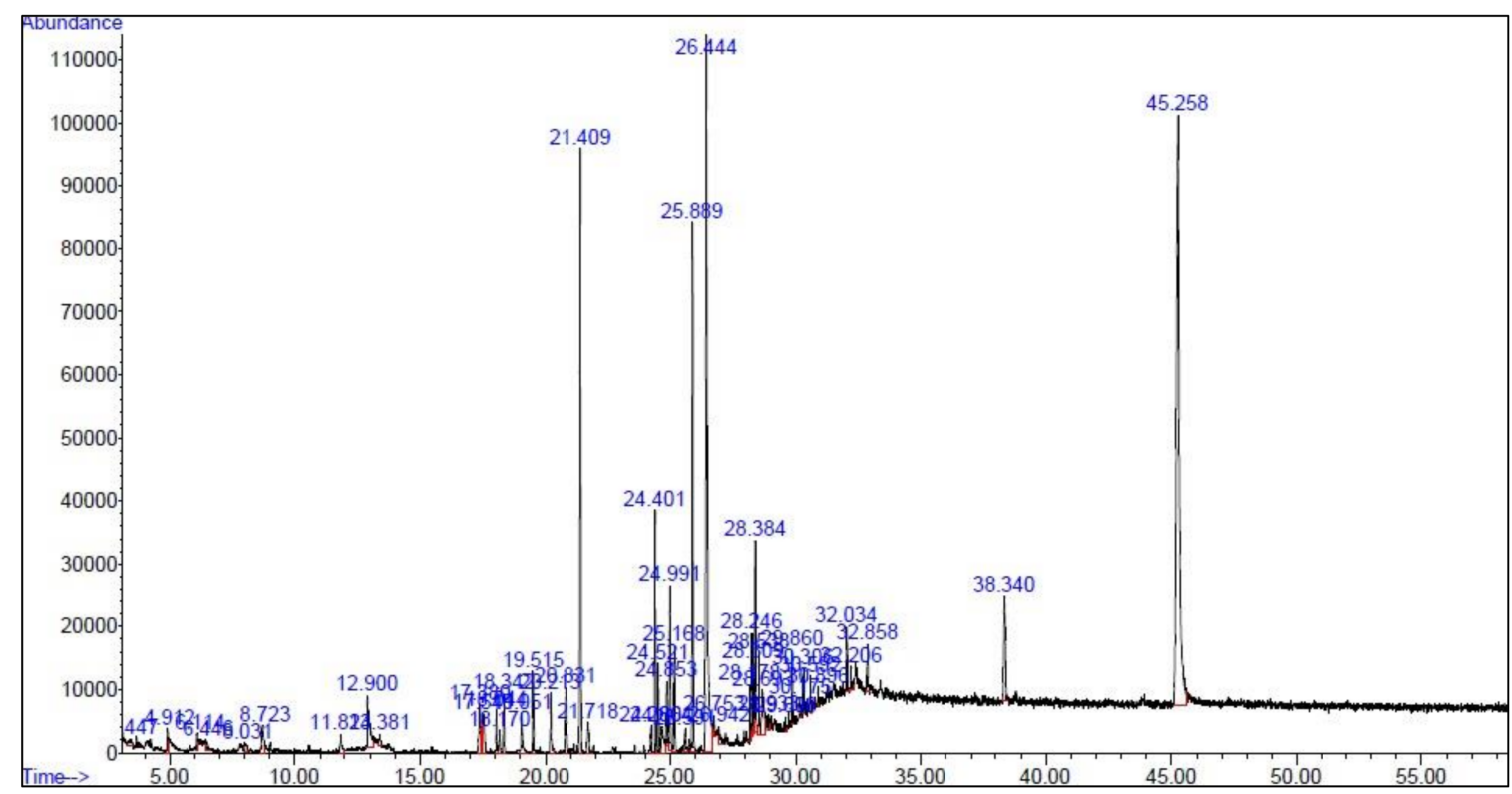

Figure 1. Gas chromatography and mass spectroscopy chromatogram of the methanolic extract of the Gracilariopsis persica alga.

Table 1. The phytocomponents were detected in the methanolic extract of the Gracilariopsis persica using gas chromatography and mass spectroscopy.

\begin{tabular}{|c|c|c|c|c|}
\hline Retension Time & Name of the Compound & Area $\%$ & Bioactivity & Reference \\
\hline 3.447 & Boron, trihydro (N-methylmethanamine-, (T-4)- & 0.36 & & \\
\hline 4.912 & 2 (3H)-Furanone, dihydro-4-hydroxy- & 0.45 & Antibacterial & [35] \\
\hline 6.114 & 1-Hepten-3-ol & 0.21 & - & \\
\hline 6.646 & D-Ribonic acid, 2,3-O-(ethoxymethylene)- & 0.37 & - & \\
\hline 8.031 & 2-Octyldodecan-1-ol & 0.19 & - & \\
\hline 8.723 & Docosane & 0.88 & Antifangal & [36] \\
\hline 11.824 & 2-Decyne & 0.46 & - & \\
\hline 12.900 & 5-Thiazoleethanol, 4-methyl- & 2.12 & $\begin{array}{l}\text { Antifungal, anti-inflammatory, } \\
\text { anti-allergic }\end{array}$ & [37] \\
\hline 13.381 & Carvacrol & 0.25 & $\begin{array}{l}\text { Anti-inflammatory, antioxidant, } \\
\text { antitumor, antibacterial }\end{array}$ & [38] \\
\hline 17.380 & 2-(1,4,4-Trimethyl-cyclohex-2-enyl)-ethanol & 1.21 & & \\
\hline 17.541 & Decamethylpentasiloxane & 0.83 & Antibacterial, antifungal & [39] \\
\hline 18.044 & 2-cyclohexene-1-one & 0.62 & Antibacterial & [40] \\
\hline 18.170 & $\begin{array}{l}\text { 10-Methyl-9-oxabicyc } \\
\text { lo[6.4.0]dodecan-1(8)-ene }\end{array}$ & 0.43 & 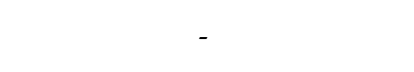 & \\
\hline 18.342 & $\begin{array}{l}\text { 2-(4H)-Benzofuranone, } \\
\text { 5,6,7,7a-tetrahydro-4,4,7a-trimethyl- }\end{array}$ & 0.76 & $\begin{array}{l}\text { Antimicrobial preservative, } \\
\text { antifungal, antibacterial }\end{array}$ & [41] \\
\hline 19.051 & 2-Propenoic acid, 3-(1-aziridinyl)-,methyl ester & 0.85 & & \\
\hline 19515 & Diethyl Phthalate & 1.06 & Antioxidant & [42] \\
\hline 20.213 & Methanone, diphenyl- & 0.98 & Antibacterial, antifungal & [43] \\
\hline 20.831 & Cyclododecasiloxane, tetracosamethyl- & 1.37 & $\begin{array}{l}\text { Antimicobial, antirheumatic } \\
\text { antispasmodic }\end{array}$ & [44] \\
\hline $\begin{array}{l}21.409 \\
21.718\end{array}$ & $\begin{array}{l}\text { Heptadecane } \\
\text { n-Dodecanal }\end{array}$ & $\begin{array}{l}7.71 \\
0.66\end{array}$ & $\begin{array}{l}\text { Anticancer, anti-inflammatory } \\
\text { Antibacterial }\end{array}$ & {$[38]$} \\
\hline 24.230 & Cyclododecasiloxane, Tetracosamethyl- & 0.39 & $\begin{array}{l}\text { Antimicobial, antirheumatic } \\
\text { antispasmodic }\end{array}$ & [44] \\
\hline 24.662 & Caffeine & 0.97 & Antibacterial, antifungal & [45] \\
\hline 24.401 & Bicyclo[3.1.1] heptane, 2,6,6-trimethyl Pinane & 3.17 & Antifungal & [46] \\
\hline 24.521 & 11-Dodecen-2-one & 1.13 & & \\
\hline
\end{tabular}


Table 1. Cont.

\begin{tabular}{|c|c|c|c|c|}
\hline Retension Time & Name of the Compound & Area \% & Bioactivity & Reference \\
\hline 24.853 & E-10-Methyl-11-tetradecen-1-ol acetate & 0.76 & & \\
\hline 24.991 & Isobutyl phthalate & 2.25 & Antibacterial, antifungal & [42] \\
\hline 25.168 & Neophytadine & 1.66 & Antimicrobial, anti-inflammatory & [47] \\
\hline 25.591 & 2-Propenoic acid, 2-methyl- & 0.43 & Antibacterial, antifungal & [48] \\
\hline 25.889 & Palmitic acid methyl ester & 6.66 & Antibacterial, antifungal & [41] \\
\hline 26.444 & Palmitic acid & 17.11 & Antibacterial, antifungal & [49] \\
\hline 26.753 & Oleic acid & 0.24 & Antibacterial, antifungal & [49] \\
\hline 26.942 & 1-Decanol, 2-hexyl- & 0.46 & Antimicrobial & [50] \\
\hline 28.178 & Linolelaidic acid, methyl ester & 0.66 & Antibacterial, antifungal & [41] \\
\hline 28.246 & Oleic acid methyl ester & 1.18 & Antibacterial, antifungal & [51] \\
\hline 28.309 & Oleic acid methyl ester & 0.94 & Antibacterial, antifungal & [41] \\
\hline 28.384 & Phytol & 2.34 & Antibacterial, antifungal & [52] \\
\hline 28.538 & Stearic acid methyl ester & 1.01 & Antibacterial, antifungal & [41] \\
\hline 28.693 & 9-Hexadecenoic acid & 1.73 & Antibacterial, inflammator & [52] \\
\hline 28.933 & 9-Hexadecenoic acid & 0.32 & Antibacterial, inflammator & [52] \\
\hline 29.608 & E-11-Tetradecenoic acid & 0.25 & Antibacterial, antifungal & [52] \\
\hline 29.860 & Hexadecanedioic acid & 0.93 & Antimicrobial, anti-inflammatory & [52] \\
\hline 30.175 & 9-Borabicyclo[3.3.1]nonane, dimethylamino)propyl] & 0.27 & - & \\
\hline 0.306 & $(-)$-18-noramborx & 0.45 & - & \\
\hline 30.592 & Trisiloxane, 1,1,1,3,5,5,5-heptamethyl & 0.53 & Antifungal & [53] \\
\hline 30.896 & Hexamethylcyclotrisiloxane & 0.28 & Antimicrobial & [54] \\
\hline 32.034 & 1,3-Bis(trimethylsilyl)benzene & 0.79 & - & \\
\hline 32.206 & p-Bis(trimethylsilyl)benzene & 0.47 & - & \\
\hline 32.858 & Phthalic acid,bis(2-ethylhexyl) ester & 0.75 & Antibacterial, antifungal & [35] \\
\hline 38.340 & N-Methyl-1-adamantane acetamide & 2.52 & Antimicrobial & [55] \\
\hline 45.258 & Cholest-5-en-3-ol (3.beta.)- & 27.64 & Antibacterial & {$[56,57]$} \\
\hline
\end{tabular}

\subsection{Quantitative Analysis of Phenolic Compounds Determined Using HPLC}

Figure 2 displays the standard HPLC chromatogram of all the recorded compounds at 250, 272, and $310 \mathrm{~nm}$. According to Figure 2, all the studied compounds responded to the three spectra and were isolated successfully. The compounds of the alga extract were also separated using the same method at the same wavelengths, and they were identified using the standard graph (Figure 3a-c).

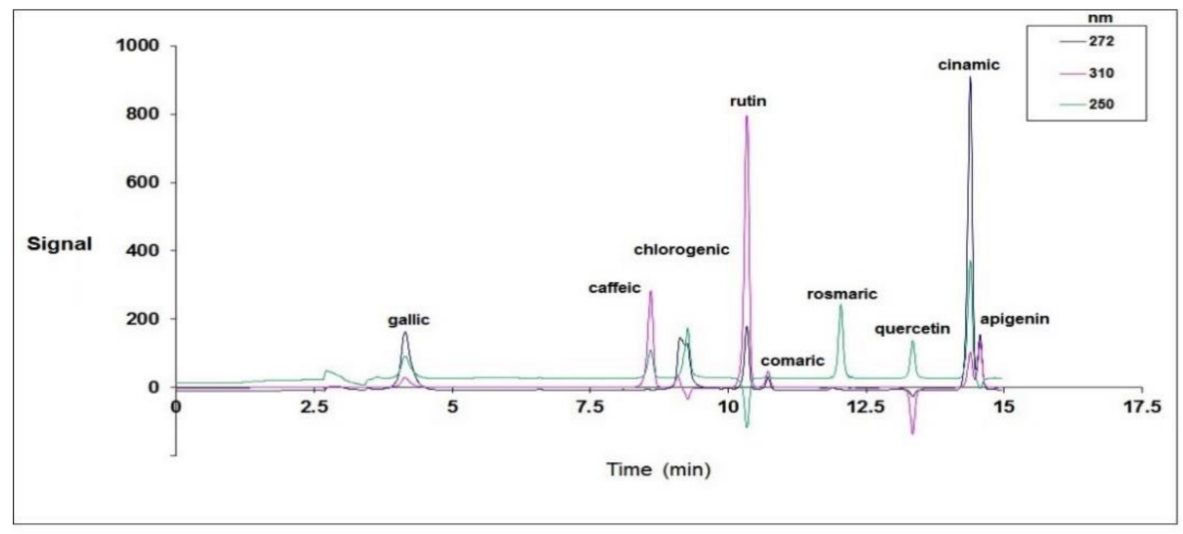

Figure 2. The standard graph of the phenolic compounds in the HPLC chromatogram. 


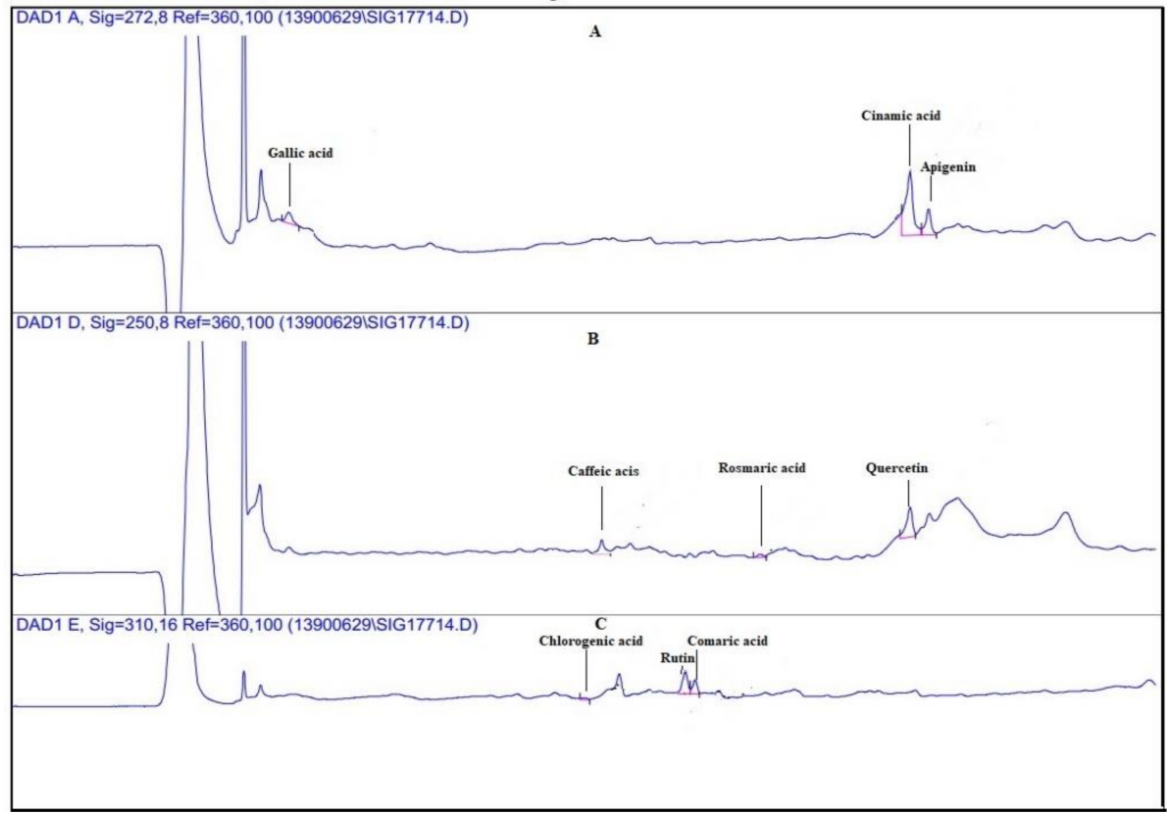

Figure 3. The diagram of identifying the phenolic compounds using the HPLC method at three wavelengths of (A) $272 \mathrm{~nm}$, (B) $250 \mathrm{~nm}$, and (C) $310 \mathrm{~nm}$.

The quantitative results for the phenolic compounds using the HPLC method showed that the most abundant phenols in G. Persica were rosmarinic acid $(20.9 \pm 0.41 \mathrm{mg} / \mathrm{kg}$ DW) and quercetin $(11.21 \pm 0.20 \mathrm{mg} / \mathrm{kg}$ DW), and the least abundant was cinnamic acid $(1.4 \pm 0.10 \mathrm{mg} / \mathrm{kg} \mathrm{DW})$ (Figures 3 and 4$)$.

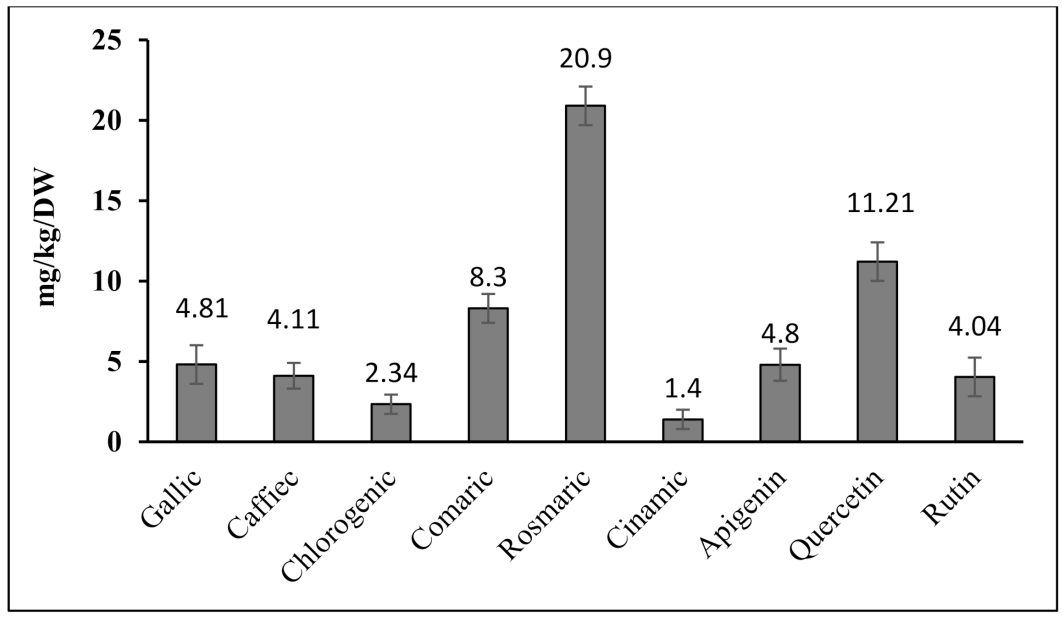

Figure 4. The quantity of the phenolic compounds identified using the HPLC method in G. persica (columns are mean $\mathrm{SD} \pm 3$ replications and vertical bars show standard deviation).

\subsection{Antifungal Activity}

Based on the results, as the concentration of the G. persica extract was increased, the growth of B. cinerea, P. oryzae, A. niger, and P. expansum was inhibited to a significantly higher extent (Figure 5). The lowest MGI in all four fungi was 35.18, 16.88, 24.50, and $37.21 \%$ recorded at the extract volume of $200 \mu \mathrm{L}$, respectively. The mycelial growth of $B$. cinerea and P. expansum was completely inhibited at an extract volume of $800 \mu \mathrm{L}$, and that of $P$. oryzae and A. niger was fully inhibited at the extract rate of $1000 \mu \mathrm{L}$ (Figure 5). 


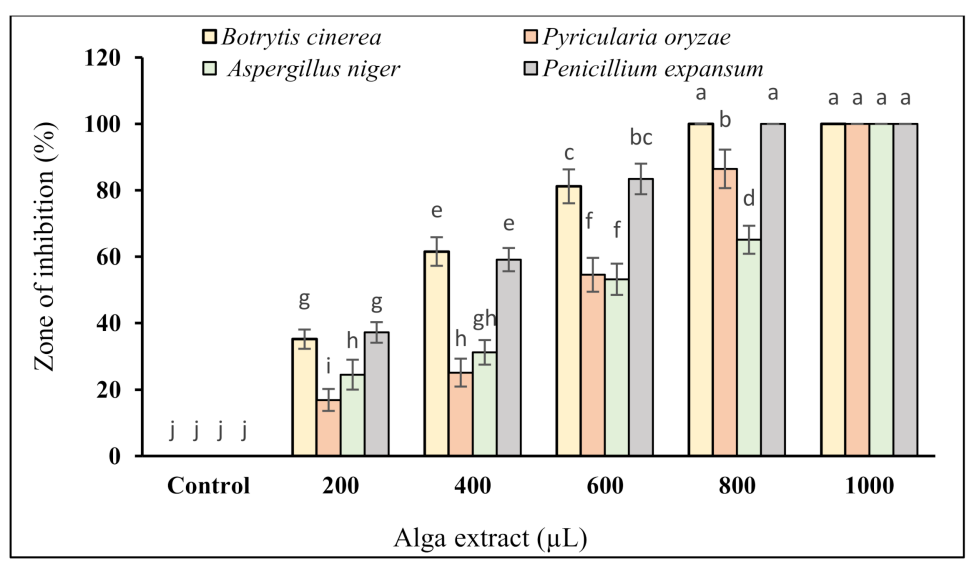

Figure 5. The effect of the G. persica extracts at volumes, 200, 400, 600, 800, and $1000 \mu \mathrm{L}$ on the mycelial growth inhibition of B. cinerea, P. oryzae, A. niger, and P. expansum (columns are mean SD \pm 3 replications, vertical bars show standard deviation, and different letters imply significant differences at the $p<0.05$ level based on Duncan's test.).

The results as to the effect of the alga extract on the mycelial growth of the studied fungi revealed a clear dose-response of the extract. The $100 \%$ inhibition was achieved at 800 and $1000 \mu \mathrm{L}$ for B. cinerea and P. expansum (Figure S1) and $1000 \mu \mathrm{L}$ for P. oryzae and A. niger (Figure S2).

\section{Fungistatic}

The fungistatic effect of various concentrations of the extract was observed as inhibition of mycelial growth. However, re-culturing the mycelial growth following the re-inoculation into the fresh medium resulted in the re-growth of the fungal mycelium in the new medium, implying that the alga extract could only inhibit the growth of the fungi (fungistatic).

In the study of fungicidal or fungistatic effects of extracts at concentrations that completely inhibited mycelium growth, the re-cultures resulting from the transfer of the fungi-containing ring to the PDA culture medium showed that the fungi reappeared and grew after 5-7 days on the fresh culture medium. The results revealed that $P$. oryzae and $A$. niger started to grow after 5 days and $P$. expanstum and B. cinerea started to grow after 7 days. During the study period (7 days), the growth of mycelium in the re-cultures of the control fungi was completely evident from the second day, and it was much higher (up to $90 \%$ ) at the end of 7 days than the re-cultures performed at concentrations in which mycelium growth was completely inhibited. These results indicate that the algae extract only inhibited the growth of fungi and fungicidal properties were observed in none of the extract concentrations.

\section{Discussion}

The results obtained from the GC-MS analysis of this study specify that G. persica showed a large number of bioactive compounds with antioxidant, antibacterial, and antifungal properties. There are various reports about the compounds derived from macroalgae as a potential source of biochemical and medicinal properties including antibacterial [57], antifungal [58], antiviral [59], antioxidant [60], and anti-inflammation activities [61].

The results of the present study revealed that the extract of G. persica had a high potential to inhibit the mycelial growth of plant pathogenic fungi. Previous research findings have indicated that alga extracts have agents for the biological control of the growth of hyphae and germination, an increase in intracellular holes (vacuolization), and the disruption of the functioning of fungal cells [62]. On the other hand, research on different species of Gracilaria has revealed this genus' antibacterial and antifungal activities. In this regard, Singh and Raadha [63] studied the G. corticata extract. They found that this 
species, at a rate of $1000 \mu \mathrm{L}$, could inhibit the growth of human pathogenic bacteria and fungi, including Salmonella typhimurium, Escherichia coli, Staphylococcus aureus, and Candida albicans, and was a natural source of antibiotics. Dayuti [64] also reported the antibacterial activity of G. verrucosa against S. typhimurium and E. coli. A study on the antifungal and antibacterial properties of the G. confervoides extract showed that $100 \mu \mathrm{L}$ of the G. confervoid extract could prevent the aerial mycelial growth of the cucumber pathogens Rhizoctonia solani and Macrophomina phaseolinae [58]. This is consistent with our findings as to the fungistatic activity of the G. persica extract. In an experiment, Kolanjinathan and Stella [65] found that G. corticata could inhibit the growth of Aspergillus flavus, A. fumigatus, and A. niger, as well as the human pathogen albicans. The minimum inhibitory rate of this extract was estimated at $2-16 \mathrm{mg} / \mathrm{mL}$. This is in agreement with our findings as to the antifungal property of G. persica in inhibiting the growth of A. niger.

The results of HPLC analysis in our study showed that G. persica is rich in polyphenolic compounds. It is now well established that the antifungal activity of alga extracts may be related to the presence of phytochemicals, e.g., tannins and phenols. Phenolic compounds are likely to influence the growth and metabolism of fungi [66]. Sea resources are the most enormous remaining reservoirs of natural molecules, which are assessed for therapeutic activities and provide valuable ideas for developing new medications against cancer, microbial infections, and inflammations [67]. Although terrestrial biodiversity constitutes the basis of the pharmaceutical industry, oceans have rich biodiversity and can produce commercially invaluable modern compounds. A comparison of our findings with those of other studies confirms that G. persica is a rich source of biological components.

Some phytocompounds, which combine alkaloids, flavonoids, and saturated and unsaturated fatty acids, have antimicrobial, anti-inflammation, anti-cancer, anti-coagulant, and anti-arrhythmic activities. According to the results of GC-MS, most of the compounds detected in the methanolic extract of G. persica (36 out of the 50 detected components) are compounds whose antimicrobial and antifungal activities have already been documented. These interpretations corroborate the findings of current research (Table 1).

The results of HPLC revealed that G. persica had invaluable phenolic compounds, e.g., rosmarinic acid and quercetin, implying its antioxidant effect. It has been reported that the difference in plant extracts' biological activity depends on their constituents; therefore, a single compound may be responsible for an extract's effects alone or in synergy with other compounds [68].

Polyphenols are a remarkable group of plant metabolites that have an efficient antimicrobial performance. A number of studies have postulated about the interaction of the synergy of polyphenols with antibiotics against microbial resistance, e.g., epigallocatechin gallate of green tea [69], tellimagrandin I, and rugosin B of Rosa floribunda 'Dubline Bay' (aka 'MACdub') [70], and the synergy of rosmarinic acid and antibiotics against methicillinresistant Staphylococcus aureus [71]. Likewise, the antimicrobial effect of quercetin as the second dominant phenolic compound in G. persica against Escherichia coli, Staphylococcus aureus, and Pseudomonas fluorescens [72], and the antifungal effects of quercetin and rutin against Cryptococcus spp. [73] have been documented. It has been reported that these compounds can change the structure of the cell membrane, thereby destroying the plasma membrane integrity in fungal cells and increasing its permeability, which results in an increase in the $\mathrm{K}^{+}$outflow from the cytoplasm of fungal cells. These effects may cause the polarity of the membrane to be lost by altering ion transport, or they may reduce energy production (ATP) by altering the membrane structure through impairing glucose uptake or inhibiting the enzymes involved in oxidative stress or phosphorylation precursor. The increase in cytoplasm membrane permeability ultimately leads to cell death due to the dispersion and loss of the cell $\mathrm{pH}$ gradient, a decline in the ATP level, and the failure of the proton driving force. Indeed, nutrient uptake, nucleic acid synthesis, and ATPase activity sections are most damaged in the tissues of the fungi [74,75].

The experimental evidence of current research regarding the examination of polyphenolic compounds in G. persica showed that quercetin was the highest among the flavonoid 
compounds. The possible activity of flavonoids may also be involved in mitochondrial damage and ROS production by inducing the transcription factors related to apoptosis and increasing the level of proptose proteins [76]. Hwang et al. [77] revealed that flavonoids disturbed the performance of mitochondria in the C. albicans strain by increasing the ROS level. The elevated intracellular ROS level and the disturbed mitochondrial performance play a significant role in apoptosis induction [78,79]. Quercetin has two aromatic rings in its structure and can penetrate the phospholipid membrane [80], where it damages DNA by inducing oxidative damage and, finally, cause cell death by apoptosis, which is an irreversible process [81].

\section{Conclusions}

Herbal medicines play a significant role in human health and are an inspiring source of new medicinal compounds. It can be concluded from the results of the present study that G. persica has a high potential to be used in the pharmaceutical industry to improve health owing to its different compounds with antimicrobial activity.

The inhibitory effect of the alga on the growth of plant pathogenic fungi in vitro is apparent from our experimental evidence. Thus, this alga might be used to produce an environmentally friendly, reliable, and economic antifungal agent to control $B$. cinerea, $P$. oryzae, A. niger, and P. expansum. This can be a high potential alternative to highly toxic chemical fungicides in plant disease management. The fungicidal efficacy still has to be shown in vivo. Above all, our results suggest that the algae in the Persian Gulf and Oman Sea can be a rich source of different macroalgae species with unique antimicrobial activities, which may have various applications in agriculture and the control of plant disease in the future.

Supplementary Materials: The following are available online at https:/ /www.mdpi.com/article/10 .3390 / plants10091781/s1, Figure S1: The effect of different concentrations of the G. persica extract (control, 400, and $1000 \mu \mathrm{L}$ ) on the mycelial growth of B. cinerea and P. expansum. Figure S2: The effect of different concentrations of the G. persica extract (control, 400, and $1000 \mu \mathrm{L}$ ) on the mycelial growth of P. oryzae and A. niger.

Author Contributions: Writing—original draft, methodology, and formal analysis, L.P.; conceptualization, supervision, and project administration, S.S.M.; writing-editing and proofreading and formal analysis, R.Z.S. and H.A.E.E. All authors have read and agreed to the published version of the manuscript.

Funding: This work was funded by RMC, Universiti Teknologi Malaysia (UTM), Malaysia through grant No. R.J130000.7609.4C336 and R.J130000.7609.4C359.

Institutional Review Board Statement: Not applicable.

Informed Consent Statement: Not applicable.

Data Availability Statement: Not applicable.

Acknowledgments: H.A.E. would like to thank RMC, Universiti Teknologi Malaysia (UTM), Malaysia for financial support through grant No. R.J130000.7609.4C336 and R.J130000.7609.4C359.

Conflicts of Interest: The authors declare no conflict of interest.

\section{References}

1. Lee, R.E. Phycology; Cambridge University Press: Cambridge, UK, 2008.

2. Mishra, V.K.; Temelli, F.; Ooraikul, B.; Shacklock, P.F.; Craigie, J.S. Lipids of the red alga, Palmaria palmata. Bot. Mar. 1993, 36, 169-174. [CrossRef]

3. Mohamed, F.; Namitha, K.K.; Chidambara Murthy, K.N.; Mahadeva Swamy, M.; Sarada, R.; Khanam, S.; Subbarao, P.V.; Ravishankar, G.A. Chemical composition, iron bioavailability and antioxidant activity of Kappsphycus alvarezi. J. Agric. Chem. 2005, 53, 792-797.

4. Plaza, M.; Santoyo, S.; Jaime, L.; Reina, G.G.B.; Herrero, M.; Senorans, F.J.; Lbanez, E. Screening for bioactive compounds from algae. J. Pharmac. Biomed. Anal. 2010, 51, 450-455. [CrossRef] [PubMed] 
5. Al-Saif, S.S.A.; Abd-Alraouf, N.; El-Wazanani, H.A.; Aref, I.A. Antibacterial substances from marine algae isolated from Jeddah coast of Red sea, Saudi Arabia. Sau. J. Biolog. Sci. 2014, 14, 57-64. [CrossRef] [PubMed]

6. Righini, H.; Roberti, R.; Baraldi, E. Use of algae in strawberry management. J. Appl. Phyco. 2018, 30, 3551-3564. [CrossRef]

7. Soares, A.R.; Robaina, M.C.S.; Mendes, G.S.; Silva, T.S.L.; Gestinari, L.M.S.; Pamplona, O.S.; Yoneshigue-Valentin, Y.; Kaiser, C.R.; Romanos, M.T.V. Antiviral activity of extracts from Brazilian seaweeds against herpes simplex virus. Rev. Bras. Farmacogn. Braz. J. Pharmacogn. 2012, 22, 714-723. [CrossRef]

8. Sagar, A.; Sayyed, R.Z.; Ramteke, P.W.; Sharma, S.; Marraiki, N.; Elgorban, A.E.; Syed, A. ACC deaminase and antioxidant enzymes producing halophilic Enterobacter sp. PR14 promotes the growth of rice and millets under salinity stress. Physiol. Mol. Biol. Plants 2020, 26, 1847-1854. [CrossRef] [PubMed]

9. Basu, A.; Prasad, P.; Das, S.N.; Kalam, S.; Sayyed, R.Z.; Reddy, M.S.; Enshasy, H.E. Plant Growth Promoting Rhizobacteria (PGPR) as Green Bioinoculants: Recent Developments, Constraints, and Prospects. Sustainability 2021, 13, 1140. [CrossRef]

10. Hamid, B.; Zaman, M.; Farooq, S.; Fatima, S.; Sayyed, R.Z.; Baba, Z.A.; Sheikh, T.A.; Reddy, M.S.; El Enshasy, H.; Gafur, A.; et al. Bacterial Plant Biostimulants: A Sustainable Way towards Improving Growth, Productivity, and Health of Crops. Sustainability 2021, 21, 2856. [CrossRef]

11. Saharan, V.; Sharma, G.; Yadav, M.; Choudhary, M.K.; Sharma, S.S.; Pal, A.; Biswas, P. Synthesis and in vitro antifungal efficacy of $\mathrm{Cu}$-chitosan nanoparticles against pathogenic fungi of tomato. Int. J. Biol. Macromol. 2015, 75, 346-353. [CrossRef]

12. Dean, R.; Van Kan, J.A.; Pretorius, Z.A.; Hammond-Kosack, K.E.; Di Pietro, A.; Spanu, P.D.; Rudd, J.J.; Dickman, M.; Kahmann, R.; Ellis, J.; et al. The Top 10 fungal pathogens in molecular plant pathology. Mol. Plant. Pathol. 2012, 13, 414-430. [CrossRef] [PubMed]

13. Wang, X.; Lee, S.; Wang, J.; Ma, J.; Bianco, T.; Jia, Y. Current advances on genetic resistance to rice blast disease. In Rice-Germplasm, Genetics, and Improvement; Yan, W., Bao, J., Eds.; InTech: London, UK, 2014; pp. 195-217.

14. Bautista-Baños, S. Postharvest Decay: Control Strategies; Elsevier: Amsterdam, The Netherlands; Academic Press: San Diego, CA, USA, 2014; p. 383.

15. Pitt, J.I.; Hocking, A.D. Fungi and Food Spoilage, 3rd ed.; Springer Science + Business Media, LLC: New York, NY, USA, 2009; p. 519.

16. Palencia, E.R.; Hinton, D.M.; Bacon, C.W. The black Aspergillus species of maize and peanuts and their potential for myctoxin production. Toxins 2010, 2, 399-416. [CrossRef]

17. Ziani, K.; Fernandez-Pan, I.; Royo, M.; Maté, J.I. Antifungal activity of films and solutions based on chitosan against typical seed fungi. Food Hydrocolloids 2009, 23, 2309-2314. [CrossRef]

18. Kwon, J.H.; Jeong, S.G.; Hong, S.B.; Chae, Y.S.; Park, C.S. Occurrence of blue mold on sweet persimmon (Diospyros kaki) caused by Penicillium expansum. Res. Plant Dis. 2006, 12, 290-293. [CrossRef]

19. Gao, L.L.; Zhang, Q.; Sun, X.Y.; Jiang, L.; Zhang, R.; Sun, G.Y.; Zha, Y.L.; Biggs, A.R. Etiology of moldy core, core browning, and core rot of Fuji apple in China. Plant Dis. 2013, 97, 510-516. [CrossRef]

20. Tannous, J.; Atoui, A.; El Khoury, A.; Francis, Z.; Oswald, I.P.; Puel, O.; Lteif, R. A study on the physicochemical parameters for Penicillium expansum growth and patulin production: Effect of temperature, pH, and water activity. Food Sci. Nutr. 2016, 4, 611-622. [CrossRef]

21. Kalam, S.; Basu, A.; Ahmad, I.; Sayyed, R.Z.; Enshasy, D.; Dailin, J.; Suriani, N.L. Recent understanding of soil Acidobacteria and their ecological significance: A critical review. Front. Microbiol. 2020, 11, 580024. [CrossRef]

22. Arora, H.; Sharma, A.; Sharma, S.; Haron, F.F.; Gafur, A.; Sayyed, R.Z.; Datta, R. Pythium damping-off and root rot of Capsicum annuum L.: Impacts, Diagnosis, and Management. Microorganisms 2021, 9, 823. [CrossRef] [PubMed]

23. Miah, G.; Rafii, M.Y.; Ismail, M.R.; Puteh, A.B.; Rahim, H.A.; Asfaliza, R.; Latif, M.A. Blast resistance in rice: A review of conventional breeding to molecular approaches. Mol. Biol. Rep. 2013, 40, 2369-2388. [CrossRef] [PubMed]

24. Chauhan, B.S.; Jabran, K.; Mahajan, G. Rice Production Worldwide; Springer International Publishing AG: Berlin/Heidelberg, Germany, 2017; p. 563.

25. Raven, P.H.; Evert, R.F.; Eichom, S.E. Biology of Plants, 5th ed.; Worth Publishers: New York, NY, USA, 1992.

26. Saidani, K.; Bedjou, F.; Benabdesslam, F.; Touati, N. Antifungal activity of methanolic extracts of four Algerian marine algae species. Afr. J. Biotechnol. 2012, 11, 9496-9500. [CrossRef]

27. Sahoo, D.; Yarish, C. Mariculture of seaweeds. In Phycological Methods: Algal Culturing Techniques; Andersen, R., Ed.; Academic Press: New York, NY, USA, 2005; pp. 219-237.

28. Sohrabipour, J.; Rabii, R. A list of marine algae of sea shores of the Persian Gulf and Oman Sea in the Hormozgan province. Iran. J. Bot. 1999, 8, 131-162.

29. Reshma, P.; Naik, M.K.; Aiyaz, M.; Niranjana, S.R.; Chennappa, G.; Shaikh, S.S.; Sayyed, R.Z. Induced systemic resistance by 2,4diacetylphloroglucinol positive fluorescent Pseudomonas strains against rice sheath blight. Indian J. Exp. Biol. 2018, 56, 207-212.

30. Zope, V.P.; Jadhav, H.P.; Sayyed, R.Z. Neem cake carrier prolongs shelf life of biocontrol fungus Trichoderma viridae. Indian J. Exp. Biol. 2019, 57, 372-375.

31. Liu, S. Study on the commercial cultivation of Gracilaria in south. Chi. J. Oce. Lim. 1987, 5, 281-283.

32. Kumar, C.S.; Dronamraju, V.; Sarada, L.; Ramasamy, R. Seaweed extracts control the leaf spot disease of the medicinal plant Gymnema sylvestre. Ind. J. Sci. Technol. 2008, 1, 1-5. [CrossRef] 
33. Seal, T. Quantitative HPLC analysis of phenolic acids, flavonoids, and ascorbic acid in four different solvent extracts of two wild edible leaves, Sonchus arvensis and Oenanthe linearis of North-Eastern region in India. J. Appl. Pharmacol. Sci. 2016, 6, 157-166. [CrossRef]

34. Shahi, S.K.; Patra, M.; Shukla, A.C.; Dikshit, A. Use of essential oil as botanical-pesticide against postharvest spoilage in Malus pumilo fruits. Biocontrol 2003, 48, 223-232. [CrossRef]

35. Husain, A.; Mumtaz, A.; Siddiqui, N. Synthesis, reactions and biological activity of 3-arylidene-5-(4-methylphenyl)-2(3H)furanones. J. Serb. Chem. Soc. 2009, 74, 103-115. [CrossRef]

36. Mansur Ali, S.; Ahmed Khan, N.; Sagathevan, K.; Anwar, A.; Siddiqui, R. Biologically active metabolite(s) from haemolymph of red-headed centipede Scolopendra subspinipes possess broad spectrum antibacterial activity. AMB Express 2019, 9, 1-17.

37. Paerl, R.W.; Bertrand, E.M.; Rowland, E.; Schatt, P.; Mehiri, M.; Niehaus, T.D.; Hanson, A.D.; Riemann, L.; Bouget, F.Y. Carboxythiazole is a key microbial nutrient currency and critical component of thiamin biosynthesis. Sci. Rep. 2018, 8, 8876. [CrossRef] [PubMed]

38. Magi, G.; Marini, E.; Facinelli, B. Antimicrobial activity of essential oils and carvacrol, and synergy of carvacrol and erythromycin, against clinical, erythromycin-resistant Group A Streptococci. Front. Microbiol. 2015, 6, 1-7. [CrossRef]

39. Mahmud, P.I.A.M.; Wan Ahmad, W.Y.; Ibrahim, N.; Abu Bakar, M. Antibacterial activity and major constituents of polyalthia cinnamomea basic fraction. Sains Malays. 2018, 47, 2063-2071. [CrossRef]

40. Vyas, D.H.; Tala, S.D.; Akbari, J.D.; Dhaduk, M.F.; Joshi, H.S. Synthesis, antimicrobial, and antitubercular activity of some cyclohexenone and indazole derivatives. Ind. J. Chem. 2009, 48, 1405-1410.

41. Mujeeb, F.; Bajpai, P.; Pathak, N. Phytochemical evaluation, antimicrobial activity, and determination of bioactive components from leaves of Aegle marmelos. Biol. Med. Res. Int. 2014, 2014, 1-11.

42. Al-Bari, M.A.A.; Sayeed, M.A.; Rahman, M.S.; Mossadik, M.A. Characterization and antimicrobial activities of a phthalic acid derivative produced by Streptomyces bangladeshiensis-A novel species collected in Bangladesh. Res. J. Medic. Med. Sci. 2006, 1, 77-81.

43. Uma, M.; Jothinayaki, S.; Kumaravel, S.; Kalaiselvi, P. Determination of bioactive components of Plectranthus amboinicus Lour by GC-MS analysis. N.Y. Sci. J. 2011, 4, 66.

44. Singh, H.B.; Handique, A.K. Antifungal activity of the essential oil of Hyptis suaveolens and its efficacy in biocontrol measures in combination with Trichoderma harzianum. J. Essent. Oil Res. 2007, 9, 683-687. [CrossRef]

45. Kim, Y.W.; Chun, H.J.; Kim, I.; Liu, H.; Shick Ahn, W. Antimicrobial and antifungal effects of green tea extracts against microorganisms causing vaginitis. Food Sci. Biotechnol. 2013, 22, 713-719. [CrossRef]

46. Nikitina, L.E.; Startseva, V.A.; Dorofeeva, L.; Artemova, N.P.; Kuznetsov, I.V.; Lisovskaya, S.A.; Glushko, N.P. Antifungal activity of bicylic monoterpenoids and terpeneslfides. Chem. Nat. Comp. 2010, 46, 28-32. [CrossRef]

47. Kumara Swamy, M.; Arumugam, G.; Kaur, R.; Ghasemzadeh, A.; Yusoff, M.M.; Sinniah, U.R. GC-MS-based metabolite profiling, antioxidant and antimicrobial properties of different solvent extracts of Malaysian Plectranthus amboinicus leaves. Evidence Based Compl. Altern. Medi. 2017, 2017, 1-10. [CrossRef]

48. Qi, S.H.; Xu, Y.; Gao, J.; Qian, P.Y.; Zhang, S. Antibacterial and antilarval compounds from the marine bacterium Pseudomonas rhizosphaerae. Ecol. Environ. Microbiol. 2009, 59, 229-233.

49. Chandrasekaran, M.; Senthilkumar, A.; Venkatesalu, V. Antibacterial and antifungal efficacy of fatty acid methyl esters from the leaves of Sesuvium portulacastrum L. Eur. Rev. Medicol. Pharmacol. Sci. 2011, 15, 775-780.

50. Togashi, N.; Shiraishi, A.; Nishizaka, M.; Matsuoka, K.; Endo, K.; Hamashima, H.; Inoue, Y. Antibacterial activity of long-chain fatty alcohols against Staphylococcus aureus. Molecules 2007, 12, 139-148. [CrossRef] [PubMed]

51. Pejin, B.; Savic, A.; Sokovic, M.; Glamoclija, J.; Ciric, A.; Nikolic, M. Further in vitro evaluation of the antiradical and antimicrobial activity of phytol. Nat. Prod. Res. 2014, 28, 372-376. [CrossRef] [PubMed]

52. Swamy, M.K.; Sinniah, U.R. A comprehensive review on the phytochemical constituents and pharmacological activities of Pogostemon cablin Benth.: An aromatic medicinal plant of industrial importance. Molecules 2015, 20, 8521-8547. [CrossRef]

53. Shobier, A.H.; Abdel, S.A.; Barakat, G.M. GC/MS spectroscopic approach and antifungal potential of bioactive extracts produced by marine macroalgae. Egy. J. Aqu. Res. 2016, 42, 289-299. [CrossRef]

54. Keskin, D.; Ceyhan, N.; Ugur, A.; Durgan Dbeys, A. Antimicrobial activity and chemical constituents of West Anatolia olive (Olea europaea L.) leaves. J. Food. Env. 2012, 10, 99-102.

55. Rateb, H.S.; Ahmed, H.E.; Ahmed, S.; Ihmaid, S.; Afifi, H.S. Discovery of novel phthalimide analogs: Synthesis, antimicrobial and antitubercular screening with molecular docking studies. EXCLI J. 2016, 15, 781-796.

56. Saeidniaa, S.; Permehb, P.; Goharia, A.R.; Mashinchian-Moradib, A. Gracilariopsis persica from Persian Gulf contains bioactive sterols. IJPR 2012, 11, 845-849.

57. Nirupama, R. Fungal disease of white muscardiane in silkworm, Bombyx mori L. Mun. Ent. Zool. 2014, 9, 870-875.

58. Soliman, A.S.; Ahmed, A.Y.; Abdel-Ghafour, A.; El-Sheekh, M.; Sobhy, H. Antifungal bio-efficacy of the red algae Gracilaria confervoides extracts against three pathogenic fungi of the cucumber plant. Middle East. J. Appl. 2018, 8, 727-735.

59. Kim, S.K.; Karadeniz, F. Anti-HIV activity of extracts and compounds from marine algae. Adv. Food. Nutr. Res. 2011, 64, 255-265. [PubMed]

60. Zarei Jeliani, Z.; Mashjoor, S.; Soleimani, S.; Pirian, K.; Sedaghat, F. Antioxidant activity and cytotoxicity of organic extracts from three species of green macroalgae of Ulvaceae from Persian Gulf. Modares J. Biotech. 2018, 9, 59-67. 
61. Abdelhamid, A.; Jouini, M.; Bel Haj Amor, H.; Mzoughi, Z.; Dridi, M.; Ben Said, R.; Bouraoui, A. Phytochemical analysis and evaluation of the antioxidant, anti-inflammatory, and anti-nociceptive potential of phlorotannin-rich fractions from three Mediterranean brown seaweeds. Mar. Biotechnol. 2018, 20, 60-74. [CrossRef]

62. Komari, S.S.; Kumar, V.D.; Priyanka, B. Antifungal efficacy of seaweed extracts against fungal pathogen of silkworm, Bombyx mori L. Int. J. Agric. Res. 2017, 12, 123-129. [CrossRef]

63. Singh, M.J.; Raadha, C.K. Studies on the antimicrobial potency of the marine algae-Gracilaria corticata var cylindrical and Hydroclathrus clathratus. Adv. Life Sci. Health 2015, 2, 50-55.

64. Dayuti, S. Antibacterial activity of red algae (Gracilaria verrucosa) extract against Escherichia coli and Salmonella typhimurium. Earth Environ. Sci. 2018, 137, 1-5.

65. Kolanjinathan, K.; Stella, D. Pharmacological effect of Gracilaria corticata solvent extracts against human pathogenic bacteria and fungi. Int. J. Pharmacol. Biol. Arch. 2011, 2, 1722-1728.

66. Perry, N.B.; Blunt, J.W.; Munro, M.H. Cytotoxic and antifungal 1, 4-naphthoquinone and related compounds from a New Zealand brown algae. Landsburgia quercifolia. J. Nat. Prod. 1991, 54, 978-985. [CrossRef]

67. Elena, M.; Francisco, Y.; Erickson, K.L. Mailiohydrin, a cytotoxic chamigrene dibromohydrin from a Phillippine Laurencia species. J. Nat. Prod. 2003, 64, 790-791.

68. Smit, A.J. Medicinal and pharmaceutical uses of seaweed natural products: A review. J. Appl. Phycol. 2004, 16, 245-262. [CrossRef]

69. Zhao, W.H.; Hu, Z.Q.; Hara, Y.; Shimamura, T. Inhibition of penicillinase by epigallocatechin gallate resulting in restoration of antibacterial activity of penicillin against penicillinase-producing Staphylococcus aureus. Antim. Agents Chemo. 2002, 46, 2266-2268. [CrossRef]

70. Shiota, S.; Shimizu, M.; Mizusima, T.; Ito, H.; Hatano, T.; Yoshida, T.; Tsuchiya, T. Restoration of the effectiveness of beta-lactams on methicillin-resistant Staphylococcus aureus by tellimagrandin I from rose red. FEMS Microbiol. Lett. 2000, 185, 135-138.

71. Ekambaram, P.S.; Perumal, S.S.; Balakrishnan, A.; Marappan, N.; Gajendran, S.S.; Viswanathan, V. Antibacterial synergy between rosmarinic acid and antibiotics against methicillin-resistant Staphylococcus aureus. J. Int. Ethnopharm. 2016, 5, 358-363. [CrossRef] [PubMed]

72. Arima, H.; Ashida, H.; Danno, G. Rutinen hanced antibacterial activities of flavonoids against Bacillus cereus and Salmonella enteritidis. Biosci. Biotechnol. Biochem. 2002, 66, 1009-1014. [CrossRef] [PubMed]

73. Oliveira, V.M.; Carraro, E.; Auler, M.E.; Khalil, N.M. Quercetin and rutin as potential agents antifungal against Cryptococcus spp. Braz. J. Biol. 2016, 76, 1029-1034. [CrossRef]

74. Skocibusic, M.; Bezic, N.; Dunkic, V. Food Chemistry. Phytochemical composition and antimicrobial activities of the essential oil from Satureja subspicata Vis. Grow. Croatia 2006, 96, 20-28.

75. Borghi, E.; Morace, G.; Borgo, F.; Rajendran, R.; Sherry, L.; Nile, C.; Ramage, G. New strategic insights into managing fungal biofilms. Front. Microbiol. 2015, 6, 1077. [CrossRef]

76. Lee, J.; Lee, D.G. Novel antifungal mechanism of resveratrol: Apoptosis inducer in Candida albicans. Curr. Microbiol. 2015, 70, 383-389. [CrossRef]

77. Hwang, I.; Lee, J.; Jin, H.G.; Woo, E.R.; Lee, D.G. Amentoflavone stimulates mitochondrial dysfunction and induces apoptotic cell death in Candida albicans. Mycopathologia 2012, 173, 207-218. [CrossRef]

78. Simon, H.U.; Haj-Yehia, A.; Levi-Schaffer, F. Role of reactive oxygen species (ROS) in apoptosis induction. Apoptosis 2000, 5, 415-418. [CrossRef] [PubMed]

79. Cho, J.; Lee, D.G. The antimicrobial peptide arenicin-1 promotes generation of reactive oxygen species and induction of apoptosis. Biochim. Biophys. Acta 2011, 1810, 1246-1250. [CrossRef] [PubMed]

80. Daglia, M. Polyphenols as antimicrobial agents. Curr. Opin. Biotechnol. 2012, 23, 174-181. [CrossRef] [PubMed]

81. Salvador, V.A.G. Evaluation of Apoptosis and Necrosis in Saccharomyces cerevisiae during Wine Fermentations. Ph.D. Thesis, Universidade Técnica de Lisboa, Lisbon, Portugal, 2009. 